\title{
Post- Crisis Leadership: How Leaders can Embrace Chaos
}

\author{
Dr. Denean Robinson ${ }^{1}$ \\ ${ }^{1}$ Adjuct Professor, Business Management, Prince George's Community College, Largo, Maryland, USA \\ *Correspondence: Dr. Denean Robinson, deneanrbnsn9@gmail.com
}

\begin{abstract}
Post-crisis leadership is a proactive approach where leaders must survey the internal and external environments to garner the trend of consumers buying behaviors. During this time, data analytics, re-energizing of sales and selecting a leadership style is crucial in beating your industry competitors. By reading this article, it will give leaders a new look on how to create marketing, and employee development strategies in defining their organizations. Strategic and tactical planning are key concepts needed to create internal activities for immediate implementation. Employees and leaders must work together to create a win-win situation for the consumer during these unprecedented times.

This article will discuss several main theories. Those theories include: Customer Relationship Management, Four Functions of Management and Servant Leadership. In a post-crisis pandemic, leaders must learn how to plan, organize, lead and control. The planning phase leads managers to develop an overall strategy by selecting goals, allocating resources and determining success rates of the plans to improve the overall strategy of the organization. During the second phase, organizing determines the organizational structure for executing the plans, assigns authorities, defines resource allocations and details how well tasks will be organized. In the third phase, leading will identify those who will head the plan and manage all tasks during implementation. Controlling is the last phase where continuous monitoring occurs surrounding goals completions and interventions.
\end{abstract}

Customer Relationship Management and Servant Leadership focus on strengthening relationships with your customers to determine what are the next steps in satisfying their buying behaviors. Leaders have to help customers get as much value from the product or service as they can. Organizations have to develop a meaningful partnership so the customer can generate revenue.

Finally, leaders have to be proactive, develop long-term relationship bonding, demonstrate product/service value, and generate revenue.

Keywords: Servant Leadership, Customer Relationship Management, Post-Crisis leadership

\section{ARTICLE INFORMATION}

Author(s): Dr. Denean Robinson

Received: 02 Nov, 2020; Accepted: 20 Nov, 2020; Published: 04 Dec 2020; e-ISSN: 2347-4696;

Paper Id: BMN-IJBMR-2020-14;

Citation: doi.org/10.37391/IJBMR.080405

Webpage-link: https://ijbmr.forexjournal.co.in/archive/volume-8/ijbmr-080405.html

\section{COMMENTARY}

Covid-19 has caused businesses to re-create their own new normalcy. Leaders now have to become proactive in finding innovative ideas and strategies to be able to meet an equilibrium state. Leaders will have to create a playbook of contingency activities, which will allow their organizations to have transparency in the eyes of their consumers. Every crisis causes leaders to strengthen their capabilities to re-establish the organization's vision to prepare for post-pandemic business operations. Leaders have to learn how to blend professional development opportunities and develop emerging activities to establish their position with customers and industry. CEOs and Executive leadership teams have to come up with strategies to support their employees' growth.

Leaders have to become transformative leaders and change agents. Executives have to use their influence, wisdom, and coaching in driving their organizations towards achieving their goals. Leader support means developing a learning management plan which is attached to each employee's individual performance management evaluation. The Executive leadership team has to work with the Human Resource Management Department to develop a Personal Career Plan where a SWOT analysis is used to enhance the knowledge for the employee. This new form of knowledge can assist the employee in understanding the activities they conquer and areas of improvement. Strategic steps include: offering continuing education programs or skill-soft training which will allow new information to trickle across the organization. Second step is to have your employees demonstrate this new skill, task or behavior learned. Demonstration includes giving your employees opportunities to present information to their colleagues and host internal focus groups.

The number one activity that businesses have to do is to create digital marketing for their organization. Covid-19 has changed the way organizations communicate and sell their products/services to consumers. Digital marketing is the new playbook for leadership. This playbook named digital marketing, allows organizations to incorporate multimedia 
content, uses trackable and measurable gadgets to identify customers' needs. With this playbook, organizations can become transparent by using digital marketing to build social currency, and reach global recognition. Organizations must put customers' needs under a microscope to create a fundamental repositioning of how to market their products/services. Leaders must communicate to their consumers that "We are in this Together" attitude. When organizations implement their digital marketing plan they must not over mention covid-19 all the time. Use the data analytics capture through scanning and tracking systems to advertise products/services that are not ready available to consumers in your geographical area.

Communicate what your organization is doing to ensure that employees and consumers safety is at the fore-front of your reopening phase. Advertise your organization's hours of operation and the services/products that are available for immediate consumption or use. This action will alleviate consumer anxiety. Your Executive leadership committee must work externally to keep their brand on the minds of the consumers during these chaotic times. Digital marketing allows you to do this activity in a safe and effective manner. To be successful in a pandemic, organizations must build up a virtual community at a time when normal interpersonal contact is minimized. The virtual platform becomes a new way to benchmark your financial value in the industry and with consumers. Benchmarking allows an organization to look at the goals and priorities that must be met. In addition, benchmarking compares and contrasts how you are positioned in the industry versus your competitors.

Finally, to conclude this section on "Digital Marketing", Organizations must shift their ads from 30 seconds to 15 seconds to gain influence on their consumers. Use ads that identify precise targeting. Precise targeting takes the guesswork out of what you're selling. This allows the consumers to remember your product and build a quick relationship with your products/services. Use your data obtained through Digital Marketing to make decisions about the behavior patterns of your consumers. Leaders can use this data analytics to identify trends, understand new opportunities to offer to consumers, and benchmark success rate against competitors.

The second activity is to re-energize sales. Leaders need to identify customers buying habits, identify their needs and forecast future products/services. Organizations have to teach managers to look through the lens of the consumer and fulfill their wants and needs. Identify consumer problems and create sales opportunities for the organizations. The Executive teams need to use the "Innovation Technique". The Innovation Technique helps identify who to contact, when and what to say to potential consumers. Research shows that organizations have to solve problems in a quicker manner once a crisis disrupts the market. Take this opportunity to teach consumers about new prospects or ways your organization can help society get through this crisis.
This is an excellent opportunity for organizations to visualize and re-invent themselves. Be more proactive in building credibility with your consumers. Leaders need to use foresight to think about the direction the organization will be going in the future. You have to do scenario planning where you have to make sense of inventory sales and trends escalating outside the organization. Remember that innovations force organizations to create meaningful experiences for your consumer. Solutions are derived from mega trends that are current innovations of society. Leaders must now look at consumer behavior that drives sales. Reality is revenue outcomes as a result of developing a system of re-engineering or redefining your brand. Organizations have to be prepared to eliminate barriers in their products/services sales. Invest in marketing messages that motivate consumers to support you through this post-pandemic crisis.

The last activity is defining what leadership looks like in a post-crisis pandemic. The top two leadership models are Servant and Customer Relationship Management. Servant Leadership is a model that is about serving others. Create a work environment where every employee has the ability to voice their ideas and opinions without fear of retaliation. Empower employees to make decisions and become innovative in creating opportunities for the organization. The leaders have to give immediate feedback on the employees' ideas and provide insightful industry knowledge for growth opportunities. Servant leadership is about involving a relationship with your employees so that dialogue can occur. Leaders in this model must inspire, train, serve and grow with their employees. The five characteristics of a great Servant leader is to care about others, communicate well with others, possess honesty, integrity, competence, and be risk takers. Finally, in the Servant model, effective leadership involves creating a positive team morale, and building ownership and independent thinking in the work environment. Anticipate challenges and coming up with a strategy to respond in a timely efficient manner [1-3].

The final model of leadership is the Customer Relationship Management Model. In this model, leaders pay closed details on managing their employees. This particular model enhances the need for organizations to create a strong bond with their consumers. The system uses data analytics to build a credible relationship with current and perspective consumers. Customer Relationship Management identifies key components of consumers buying and spending habits, measures the satisfaction level of consumers with the organization's products/services. Remember, this model involves the following components: customer needs, customer responses, customer satisfaction, customer loyalty, customer retention, customer complaints, and customer service. These are the areas that leaders must examine inside the organization to create a cost effective way of tracking the needs and wants of consumers, and identifying opportunities to reach more individuals to gravitate to your organization.

To conclude this section: Servant and Customer Relationship Management focuses on consumers' traits, creating consumer 
value by using performance evaluation and technology. Leaders have to possess courtesy, responsiveness, intelligence, and forecasting skill sets. Executive leaders must create a postcrisis toolbox. This toolbox is one that is filled with knowledge of how to get strategies implemented and organized employees in the right positions to be successful. In addition, this toolbox must possess the key management functions. The management functions are: planning, organizing, leading, and controlling. Planning involves identifying goals and objectives, allocating resources, and developing concrete strategic steps in creating policies, and activities to achieve the designated goals. Organizing is selecting the appropriate employees to lead in implementation of these day to day activities. Creating relationships and decision making is structured during this phase. Leading phase must create excitement, motivate, and develop commitment in carrying out the vision of the company. The last phase in management function is to monitor the execution of the activities and provide immediate remedies for problems.

To end this article, please remember leaders you must be proactive, creative, and show empathy to others. Roll up your sleeves and dive into connecting with your consumers and employees. Use data to reinvent new ways to do business and come up with best practices to use for future crises.
Embrace challenges and become innovative in developing new products or services that will generate additional revenues. Crisis will always arise, but leaders need to take this time to build relationships with their employees and consumers. This relationship will be crucial in the success of you surviving this crisis and future ones.

\section{REFERENCES}

[1] Developing the Leaders Around You: How to Help Others Reach Their Potential, by John C. Maxwell, Thomas Nelson Publishers, 1995.

[2] Principle-Centered Leadership, by Stephen R. Covey, Simon and Schuster, 1990.

[3] Why Motivating People Doesn't Work and What Does: The New Science of Leading, Energizing and Engaging, by Susan Fowler, Berrett-Koehler Publishers, Inc., 2014.

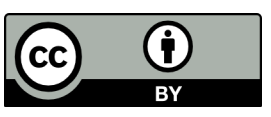

(C) 2020 by the Dr. Denean Robinson. Submitted for possible open access publication under the terms and conditions of the Creative Commons Attribution (CC BY) license (http://creativecommons.org/licenses/by/4.0/). 